\title{
Rapid zoobenthic community responses to accumulations of drifting algae
}

\author{
Alf Norkko*, Erik Bonsdorff \\ Husö Biological Station \& Department of Biology, Åbo Akademi University, FIN-20520, Åbo, Finland
}

\begin{abstract}
In the northern Baltic Sea, occurrences of benthic drifting macroalgal mats have become an increasing problem. Accumulations of algae induce hypoxia and anoxia in zoobenthos above the halocline on shallow sandy bottoms. The immediate and temporal responses of a macrozoobenthic community to accumulations of drifting algal mats were studied in a field experiment on an exposed shallow sandy bottom $(7.5 \mathrm{~m}$ depth) in the northern Baltic Sea. Experimental algal plots $(50 \times 50 \mathrm{~cm})$ corresponding to amounts recorded in the field $\left(440 \mathrm{~g} \mathrm{dwt} \mathrm{m}^{-2}\right)$ were enclosed in net-bags and attached to the bottom. Changes in zoobenthic community structure under the algae were compared with ambient control plots for a period of $5 \mathrm{wk}$ with sampling every seventh day. Community parameters (species, abundance and biomass) in the control community remained stable. Structural differences were recorded after $9 \mathrm{~d}$, and community breakdown after 16 to $21 \mathrm{~d}$ of algal cover. Only opportunists and species tolerant to hypoxia remained under the algae. High particulate organic $\mathrm{C} / \mathrm{N}$ ratios in the sediment under algal plots were recorded after $4 \mathrm{wk}$, indicating deposition of organic material from the algae to the sedimont. Intial recovery ( $5 \mathrm{~d}$ ) after terminated algal stress was rapid and dominated by a mass invasion of hydrobiid snails, possibly attracted by enrichment of the sediment. Laboratory tests on algal degradation showed a 10 -fold increase in phosphorus in the water due to nutrient leakage during hypoxia $\left(20 \% \mathrm{O}_{2}\right)$. Algal cover, and the induction of hypoxia through degradation of the algae, exhibited severe effects on zoobenthic community structure and a potential to accelerate local eutrophication. We therefore feel that the escalating amounts of drifting algae recorded in the freld are a significant threat to the coastal biota.
\end{abstract}

KEY WORDS: Drifting algae $\cdot$ Zoobenthos Hypoxia $\cdot$ Community structure $\cdot$ Recovery Baltic Sea

\section{INTRODUCTION}

During recent years, occurrences of drifting algal mats have increased in shallow coastal areas all around the Baltic Sea. Both field and experimental studies have demonstrated the negative effects on the benthos (Ólafsson 1988, Bonsdorff 1992, Norkko \& Bonsdorff 1996). The role of subtidally occurring algae is increasing and they pose a significant threat to the coastal biota by altering habitat characteristics and disturbing community interactions.

In ecological theory, the concept of disturbance and its role in structuring populations and communities has been given considerable attention (Pickett \& White 1985, Pickett et al. 1989, Lake 1990). Pickett \& White (1985) defined disturbance as a biological, chemical, or

- Present address: Husö Biological Station, FIN-22220, Emkarby Aland Islands, Finland. E-mail: anorkko@abo.fj physical event which alters or destroys the physical environment or available resources such as food and space. Disturbance might influence the structure and function of animal assemblages by directly or indirectly killing, displacing, or damaging components of the community. The effects are dependent of the frequency and intensity of the disturbance, whereas the responses depend on the inherent resilience and stability of the community. The 'intermediate disturbance hypothesis' (Connell 1978) suggests that the highest diversity in communities is found where disturbance occurs at intermediate frequencies and intensities. Frequently occurring disturbances may disrupt interactions between species and the availability of resources, producing a mosaic of patches in different sequences of a succesional pattern, thus contributing to community heterogeneity (e.g. Connell 1978, Thistle 1981. Sousa 1984, Connell \& Keough 1985, Pickett \& White 1985). 
Seasonally occurring benthic macroalgal mats are a prominent feature in coastal areas around the world and the algae have been recognized as structuring zoobenthic communities. On tidal flats, algae such as Ulva, Enteromorpha and Cladophora spp. grow attached to the intertidal soft bottoms, although looselying forms also occur (Perkins \& Abbott 1972, Nicholls et al. 1981. Soulsby et al. 1982, Reise 1983, Hull 1987. Raffaelli. et al. 1991, Isaksson \& Pihl 1992, ThyboChristesen et al. 1993). Along rocky coasts, the benthic algal mats are derived from the littoral after being fragmented, detached and transported to the sublittoral, where they form loose-lying drift algal mats (e.g. Rosenberg 1985, Thrush 1986, Olafsson 1988, Bonsdorff 1992). The coastal waters of the semienclosed brackish Baltic Sea have been shown to be susceptible to anthropogenic inputs (Nehring \& Matthäus 1991, Gray 1992) and hence the increasing eutrophication of the Baltic has become evident at most levels of the biota through increased production above the halocline (Cederwall \& Elmgren 1980, 1990, HELCOM 1990, Bonsdorff et al. 1991, Nehring \& Matthäus 1991, Jumppanen \& Mattila 1994). The archipelago waters of the northern Baltic Sea are characterized by a vast mosaic of islands and skerries with a long shoreline in relation to surface area (Bonsdorff \& Blomqvist 1993) and an average depth of only 20 to $25 \mathrm{~m}$. One obvious effect of eutrophication. is the increased production of opportunistic filamentous algae which are capable of rapidly exploiting elevated amounts of nutrients (Wallentinus 1984, Kautsky 1991). A significant increase in the production of filamentous green and brown algae has been recorded in the Archipelago Sea of southwest Finland (Mäkinen \& Aulio 1986, Jumppanen \& Mattila 1994). Mechanical loss of algal material results in the transportation of algae to the benthic systems and hence the increased production is reflected as increasing amounts of organic material in the form of drifting algae (Bonsdorff 1992, Bonsdorff et al. 1995, Norkko \& Bonsdorff 1996). These mats frequently occur on shallow sandy bottoms above $15 \mathrm{~m}$ depth with patches ranging in size from a few $\mathrm{m}^{2}$ to hectare size and modify normally uncovered areas with both promotive and repressive influences on the benthic community (Norkko \& Bonsdorff 1996). Due to the elevated amounts and frequencies of occurrence, they pose a growing threat to shallow benthic communities. Drifting algae act as a physical as well as a biological factor, with the reduction of water exchange and with algal decay inducing hypoxia and anoxia in the interstitial (Reise 1983. Hull 1987), as well as the water at the algal-sediment interface (Norkko \& Bonsdorff 1996). The response of the infaunal community to the unfavourable conditions is dependent of species-specific tolerance, mobility and size on the algal mat. We have shown earlier that short-term exposure (hours to days) at high temperatures induces an escape reaction in the infauna, enhancing prey availability (Norkko \& Bonsdorff 1996). The effects of algal mats are further pronounced since their maximum occurrence coincides with the most productive period of the year, in July and August (Bonsdorff 1992, Bonsdorff et al. 1995, Norkko \& Bonsdorff 1996). Algal mats have been acknowledged as a factor inducing widespread mortality in benthic infauna (Perkins \& Abbott 1972, Soulsby et al. 1978. 1982, Williams Cowper 1978, Nicholls et al. 1981. Thrush 1986. Hull 1987, Everett 1991, Raffaelli et al. 1991, Bonsdorff 1992, Peterson et al. 1994), Very little, however, is known about the actual mechanisms causing the impoverishment on a temporal scale. Although Thrush (1986) conducted an experiment with decaying laminarian seaweeds, illustrating the structuring potential of the algae on zoobenthos over time, most of the literature regards attached algae on tidal flats (Hull. 1987, Raffaelli et al. 1991). Loose-lying drifting algal mats are expected to affect zoobenthic communities in a more haphazard manner due to their unpredictable occurrences. The effects of the disturbance are dependent on the temporal and spatial scale of the occurrences of drifting algal mats, i.e. the frequency, constancy and amplitude of disturbance. It is therefore essential to assess the temporal response of zoobenthic communities to accumulations of drift algae in order to be able to correctly interpret their role as structuring factors on coastal zoobenthos.

We report results here from a field experiment of drifting algal mats and their importance as structuring factors on a zoobenthic community. The response of the zoobenthic community, with emphasis on the immediate temporal response to the continuous stress by drifting algal mats, was assessed in a controlled field manipulation experiment with artificially enhanced algal cover.

\section{MATERIAL AND METHODS}

Study site. The field experiment was conducted in the outermost $\AA$ land archipelago in the central. northerm Baltic Sea $\left(60^{\circ} 17^{\prime} \mathrm{N}, 19^{\circ} 49^{\prime}\right.$ E). The locality, covering an area of approximately $6 \mathrm{ha}$, is a semi-exposed sound between 2 islets and is exposed to the northwest. The depth ranges from 5 to $10 \mathrm{~m}$ and the sediment consists of medium to fine sand (median grain sizes 0.125 to $0.250 \mathrm{~mm}$; loss on ignition $-0.45 \%$ ). During summer (May to August), temperature ranges from about 6 to $17^{\circ} \mathrm{C}$ and salinity varies between 5.9 and $6.2 \%$. Oxygen saturation in the bottom water is usually high $(>100 \%)$, although local oxygen deficiency and 
anoxia has been recorded in connection with accumulations of drifting algal mats (Bonsdorff 1992). Dominating macrofauna are Macoma balthica (L.), gastropods (Hydrobia spp.), polychaetes [Pygospio elegans Claparéde, Manayunkia aestuarina (Bourne), Nereis diversicolor (O. F. Müller)] and oligochaetes. The main invertebrate predators in the area are Saduria entomon (L.) and Crangon crangon (L.), whereas the most important benthivorous fish are flounder Platichthys flesus (L.) and gobies (Norkko 1993, Bonsdorff et al. 1995). The littoral vegetation is dominated by Cladophora glomerata, Enteromorpha intestinalis, Pilayella littoralis and Fucus vesiculosus (Haldin 1994). Since the beginning of the 1990s, the production of opportunistic macroalgae has increased, as has the subsequent occurrences of drifting algal mats from 150 to an average of $450 \mathrm{~g} \mathrm{dwt} \mathrm{m}^{-2}$, and maximum biomasses of $880 \mathrm{~g} \mathrm{dwt} \mathrm{m}^{-2}$ have been recorded (Bonsdorff 1992).

During a 6 wk period (July through mid-August) in 1993, a drift algal mat covered 2 ha of the bottom. The biomass was estimated at $440 \pm 16 \mathrm{~g} \mathrm{dwt} \mathrm{m}^{-2}$. The algal mat showed signs of increasing deterioration with the development of bacterial mats (Beggiatoa spp.) on the algae. Locally the conditions under the mat were anoxic with hydrogen sulphide present.

Experimental set-up and sampling. The accumulations of drifting macroalgal mats and their impact on the zoobenthic community were studied at a depth of $7.5 \mathrm{~m}$ during $34 \mathrm{~d}$ (from August 11 to September 14, 1993). The locality chosen represented a homogenous area which had not been subjected to long-term exposure by drifting algal mats, although some short-term exposure could not be ruled out due to the unpredictable movements of the algal mat. Species composition, life-strategy and relative biomasses of the drift algal species are accounted for in Table 1 (nomenclature according to South \& Tittley 1986). Algae were collected with an Ockelmann-sledge and were carefully rinsed with seawater in the laboratory to remove macrofauna. Quantitative algal samples for the determination of biomass were taken according to Bonsdorff (1992). An amount of $\sim 510 \mathrm{~g} \mathrm{wwt}(2050 \mathrm{~g} \mathrm{wwt}$ $\mathrm{m}^{-2}=440 \mathrm{~g} \mathrm{dwt} \mathrm{m}^{-2}$ ) was sewn into 30 net-bags measuring $50 \times 50 \mathrm{~cm}$ (mesh size: $1.5 \mathrm{~cm}$ ). The net-bags were placed on the bottom and anchored with wire in 2 rows $50 \mathrm{~cm}$ apart covering an area of $22.5 \mathrm{~m}^{-2}$ The design was chosen in order to facilitate sampling

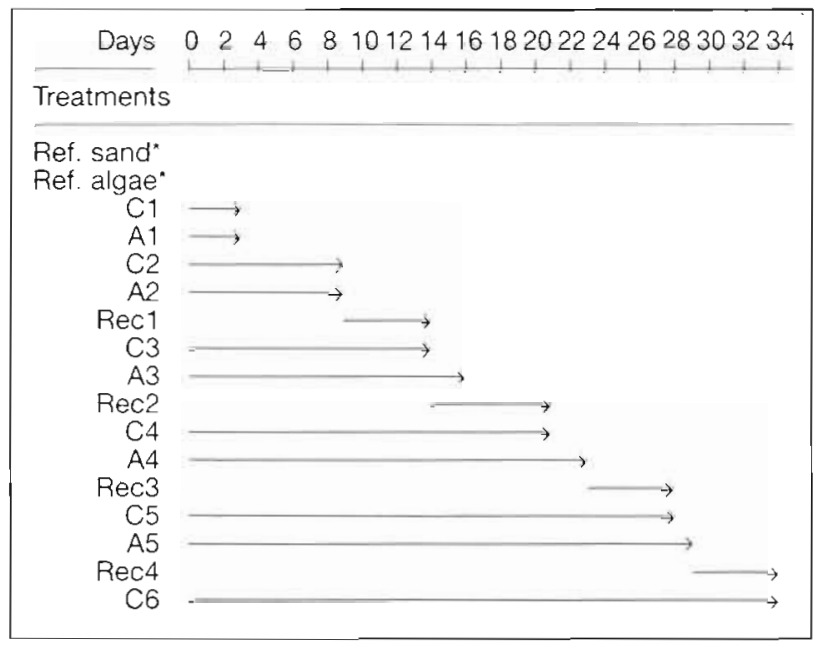

Fig. 1 Experimental design of the field experiment. Graph illustrates the treatments, their durations, and the sampling sequences. Ref. sand: reference, sand; Ref. algae: reference, algae; C1-6: controls; A.1-5: algae; Rec1-4: recovery; 'reference samples $(\mathrm{n}=5)$ from bare sand and under naturally drifting algal mats on Day 0

by SCUBA diving The net-bags were loose enough for the algae to form a naturally behaving algal mat. During the experiment, the benthic community was sampled under the algae by removing the net-bags over time (on 5 occasions) and comparing the response with ambient control situations (6 occasions, Fig. 1). On each occasion, 6 replicate net-bags with algae were randomly removed and macrofauna was sampled in

Table 1 Species composition, life strategy and relative biomasses (\% share) of the different species comprising the drifting algal mat. Life-strategy according to Wallentinus (1984). A: annuali P: perennial; t: fragments

\begin{tabular}{|c|c|c|c|}
\hline Division & Species & $\begin{array}{l}\text { Life- } \\
\text { strategy }\end{array}$ & $\begin{array}{l}\text { Biomass } \\
\text { (g dwt) }\end{array}$ \\
\hline Rhodophyta & $\begin{array}{l}\text { Ceramium tenuicorne Waern } \\
\text { Rhodomela confervoides (Huds.) Silva } \\
\text { Polysiphonia nigrescens (Huds.) Grev. }\end{array}$ & $\begin{array}{l}A \\
P \\
P\end{array}$ & $1.8 \%$ \\
\hline Phaeophyta & $\begin{array}{l}\text { Fucus vesiculosus L. } \\
\text { Chorda filum (L.) Stackh. } \\
\text { Stictyosiphon tortilis (Rupr.) Reinke } \\
\text { Dictyosiphon foeniclaceus (Hudson) Grev. } \\
\text { Pilayella littoralis (L.) Kjellmann } \\
\text { Ectocarpus siliculosus (Dillwyn) Lyngb } \\
\text { Furcellaria lumbricalis (Huds.) Lamouroux }\end{array}$ & $\left.\begin{array}{l}P \\
A\end{array}\right\}$ & $\begin{array}{l}2.9 \% \\
27.6 \% \\
63.1 \% \\
4.3 \%\end{array}$ \\
\hline $\begin{array}{l}\text { Chlorophyta } \\
\text { (Charophyta) }\end{array}$ & $\begin{array}{l}\text { Cladophora rupestris (L.) Kuetz. } \\
\text { Monostroma balticum (Aresch.) Wittr. } \\
\text { Cladophora glomerata (L.) Kuetz. } \\
\text { Tolypella nidifica (O. Mull.) Leonh. }\end{array}$ & $\begin{array}{l}\text { P } \\
A \\
A \\
-\end{array}$ & $\begin{array}{l}0.9 \% \\
+\end{array}$ \\
\hline Magnoliophyta & $\begin{array}{l}\text { Ruppia spiralis } \mathrm{L} \text {. } \\
\text { Zostera marina } \mathrm{L} \text {. }\end{array}$ & - & $\begin{array}{l}+ \\
+\end{array}$ \\
\hline
\end{tabular}


the center of the underlying sediment surface; similarily, 6 replicate control samples were randomly taken from the ambient area, using a benthic core-sampler ( $4.7 \mathrm{~cm}$ diameter, $10 \mathrm{~cm}$ into the sediment). Further, 3 s.maller core-samples $(2.5 \mathrm{~cm}$ diameter, $5 \mathrm{~cm}$ into the sediment) for the determination of loss on ignition and the analyses of particulate organic carbon (POC) and particulate organic nitrogen ( $P O N$ ) in the sediment were taken under the algae and control conditions, respectively. On every occasion, algae were collected for the measurements of POC and PON from 3 of the net-bags. After the removal of algae and the benthic samples, the plots were marked with iron rods and revisited after $5 \mathrm{~d}$ to take samples for initial faunal recovery rates. Samples for loss on ignition were determined according to Dybern et al. (1976). All macrofauna samples were fixed in $4 \%$ buffered formalin. After washing on a $0.5 \mathrm{~mm}$ mesh sieve, the remaining animals were removed, counted and identified to species/taxa under a preparation microscope (15x magnification). The sediment and algae were analyzed for POC and PON content after drying and homogenizing the samples. The measurements were done using a $\mathrm{LECO}^{\circ} \mathrm{CHN}-900$ element analyser. At the start and at the end of the experiment, water samples for the analysis of chlorophyll a were taken from the bottom water. Before the ending of each algal treatment (removal of algae), water samples were taken with a syringe underneath the algae for measurements of temperature and oxygen concentration.

The experiment consisted of 15 treatments: 6 control treatments ( $\mathrm{C} 1, \mathrm{C} 2, \mathrm{C} 3, \mathrm{C} 4, \mathrm{C} 5$ and $\mathrm{C} 6), 5$ treatments with algae (A1, A2, A3, A4 and A5) and 4 recovery treatments (Rec 1, 2, 3 and 4; Fig 1). In addition to these treatments, macrofauna samples were taken under naturally occurring drifting algal mats (Ref. algae) and from a nearby uncovered bottom area (Ref. sand) at Day 0 (start of the experiment). The experimental set-up and sampling sequences of macrofauna are presented in Fig. 1

Laboratory experiment. A small-scale experiment was conducted in. the laboratory in order to study the possible hypoxic conditions induced by algae and subsequent leakage of nutrients during decomposition. The experiment consisted of 2 treatments: control (no algae), and algae. In both treatments, 1 aquarium ( $25 x$ $35 \times 40 \mathrm{~cm}$ ) with a $6 \mathrm{~cm}$ layer of sieved and air-dried sediment was used. To the algal treatment, $175 \mathrm{~g} \mathrm{wwt}$ (2000 $\mathrm{g} \mathrm{wwt} \mathrm{m}^{-2}$ ) loose-lying algae was added on top of the sediment. Both aquaria were oxygenated with aquarium air pumps. A perforated tube was placed under the algae at the start of the experiment in order to obtain samples for the analyses of temperature and oxygen concentration. Temperature and oxygen levels were measured with a portable DO-meter (calibrated with Winkler titration) at least twice daily in both treatments. The experiment lasted $17 \mathrm{~d}_{1}$ and ended when the degradation process in the algae resulted in rapid discolouration of the water and a strong smell of hydrogen sulfide. At the end, water samples for organic and inorganic fractions of nitrogen and total phosphorus were taken from both treatments. All chemical analyses were performed according to Grasshoff et al. (1983).

Data analysis. For the analysis of the community patterns, a cluster analysis was performed for detecting natural groupings in the data (using SYSTAT $5.0^{\circ}$ ). A dendrogram was constructed based on a Euclidean distance matrix and the average-linkage (UPMGA) clustering method. The clustering was performed using the abundance values of the 7 most dominant species/taxa of the community which were constantly present in either control or algal treatments. For each replicate sample in all treatments the Shannon-Wiener diversity index $\left(H^{\prime}\right)$ and its evenness component $(J)$ was calculated. Analysis of the macrofaunal data revealed non-normality of distribution (Shapiro-Wilk $W$-test) and heterogeneity of variances (Bartlett's test). The statistical analysis was therefore performed using the non-parametric Kruskal-Wallis $H$-test (Sokal \& Rohlf 1981). In order to test for the differences between treatments, pairwise comparisons of the mean ranks were made using the formula described in Sachs (1982) which corrects for unequal sample size. Where possible, Student $t$-test and ANOVA were used. When comparing recovery after algal stress (algal treatment $\rightarrow$ recovery treatment), the non-parametric Wilcoxon signed-rank test for dependent samples was performed. All data are presented as mean values \pm standard error $(\bar{x} \pm \mathrm{SE}) \mathrm{m}^{-2}$

\section{RESULTS}

\section{Nutrient leakage from macroalgae}

The hydrographical conditions were stable throughout the experiment (Table 2). Average temperature in the control treatment was $9.6 \pm 2.1^{\circ} \mathrm{C}$ and oxygen saturation $98 \pm 1 \%$. The temperature under algae was significantly higher (pooled data of $17 \mathrm{~d}_{i} \mathrm{p}<0.001$, Student $t$-test) than in the water above the algae. Within $24 \mathrm{~h}$, the oxygen saturation declined to below $20 \%$ oxygen saturation and was stable over time with an average of $21 \pm 2 \%$ oxygen saturation under algae (Table 2). The hypoxic conditions under the algae gave a 10 -fold elevation of total phosphorous in the water compared to control (total $-\mathrm{P}=1.0 \mathrm{mg} \mathrm{l^{-1 }}$ under algae vs $0.09 \mathrm{mg} \mathrm{l}^{-1}$ in control), indicating a release from the decomposing algae under hypoxia. In the algal treatment the inorganic nitrogen fractions $\left(\mathrm{NH}_{4}{ }^{+}, \mathrm{NO}_{2}{ }^{-}\right.$and 
Table 2. Hydrographic and physico/chemical conditions in the aquaria from the laboratory experiment on the degradation of an algal mat. Control: no algae; Algae: algal biomass corresponding to $2000 \mathrm{~g} w w \mathrm{~m}^{2}$; Under/Over: conditions under and over the algal mat

\begin{tabular}{|c|c|c|c|}
\hline \multirow[t]{2}{*}{ Conditions } & \multirow[t]{2}{*}{ Control } & \multicolumn{2}{|c|}{ Algae } \\
\hline & & Under & Over \\
\hline \multicolumn{4}{|l|}{ Temperature } \\
\hline $\bar{X}^{\circ} \mathrm{C} \pm \mathrm{SE}$ & $9.6 \pm 2.1$ & $9.8 \pm 2.1$ & $9.5 \pm 2.3$ \\
\hline Min.-max. ${ }^{\circ} \mathrm{C}$ & $7.2-11.8$ & $6.7-11.9$ & $6.4-11.6$ \\
\hline \multicolumn{4}{|l|}{ Oxygen } \\
\hline $\bar{x} \% \pm \mathrm{SE}$ & $98 \pm 1$ & $21 \pm 2$ & $92 \pm 1$ \\
\hline Min.-max. $1 / \%$ & $96-109$ & $1-99$ & $73-99$ \\
\hline Total P (mg l $\left.{ }^{-1}\right)$ & 0.09 & 1.0 & 0.54 \\
\hline Total $N\left(\mathrm{mg} \mathrm{l}^{-1}\right)$ & 1.5 & 2.9 & 1.8 \\
\hline $\mathrm{NH}_{4}$ & 0.11 & 0 & 0 \\
\hline $\mathrm{NO}_{2}$ & 0.02 & 0 & 0 \\
\hline $\mathrm{NO}_{3}$ & 0.66 & 0.04 & 0.03 \\
\hline Total organic N & 0.71 & 2.9 & 1.8 \\
\hline
\end{tabular}

$\mathrm{NO}_{3}{ }^{-}$) were lower than in the control, indicating a shift from denitrification to the reduction of sulfate $\left(\mathrm{S}_{2}{ }^{-}\right)$. This is confirmed by the presence of $\mathrm{H}_{2} \mathrm{~S}$ (strong smell) (Table 2) Further, heterotrophic bacteria such as Beggiatoa spp. which occur at the interface between the anoxic sulfide-liberating zone and the overlying oxic zone are known to utilize ammonia $\left(\mathrm{NH}_{4}{ }^{+}\right)$and nitrite $\left(\mathrm{NO}_{2}{ }^{-}\right.$) (Strohl 1989). The large fraction of organically bound nitrogen (99\% of the total nitrogen pool) could reflect high biomasses of bacteria (Table 2 ).

\section{Observations from the study site}

The algae enclosed in net-bags were rapidly colonized by a large number of grazing and predatory invertebrates. The most dominant faunal components were gastropods (Hydrobia spp.), gammarid amphipods, the isopods Idothea balthica and Saduria entomon, the nemertean Prostoma obscurum, the polychaete Nereis diversicolor and turbellarians (Table 3). After $9 \mathrm{~d}$ (A2, Fig 1), the sediment surface under the algal treatments was completely black, adult Macoma balthica were noted on the sediment surface and some clams had migrated into the algae. The same phenomena with clams on the sediment surface and the appearance of a black sediment surface were observed under natural accumulations of

Table 3. List of species/taxa found in the set of treatments (Control, Under algae, Recovery). +: Species found; -: not found; - pooled occurrences from the last 2 sampling occasions in control (C5 and C6) and under algae (A.4 and A.5). Last column (In algae) indicates the species recorded $1 \mathrm{n}$ algal mats and is based on qualitative data from the experiment and field surveys

\begin{tabular}{|c|c|c|c|c|c|}
\hline Family & Species/taxa & Control & Under algae & Recovery & In algae \\
\hline \multirow[t]{8}{*}{ Mollusca } & Thedoxus fluviatills (L.) & + & + & - & + \\
\hline & Lymnea peregra (Müller) & - & - & - & + \\
\hline & Hydrobia ventrosa (Montagu) & - & - & + & + \\
\hline & Hydrobla ulvae (Pennant) & • & + & + & + \\
\hline & Mytilus edulis L. & + & + & + & + \\
\hline & Cerastoderma glaucum (Bruguire) & - & + & - & + \\
\hline & Macoma balthica (L.) & - & - & + & + \\
\hline & Embletonia pallida Alder + Hancock & - & - & - & + \\
\hline \multirow[t]{8}{*}{ Crustacea } & Sadura entomon (L.) & - & - & + & + \\
\hline & Idothea baltica Pallas & - & - & - & + \\
\hline & Jaera albifrons Leach (coll.) & - & - & - & + \\
\hline & Corophium volutator (Pallas) & - & - & - & + \\
\hline & Gammarus oceanicus Segerstrále & - & - & - & + \\
\hline & Gammarus spp. & - & + & + & + \\
\hline & Crangon crangon $(\mathrm{L})$. & - & - & - & + \\
\hline & Ostracoda & - & + & + & - \\
\hline \multirow[t]{4}{*}{ Polychaeta } & Nereis diversicolor O.F. Müller & - & • & + & + \\
\hline & Harmothoe sarsi (Kunberg) & + & - & - & + \\
\hline & Pygospio elegans Claparede & $\cdot$ & + & + & - \\
\hline & Manayunkia aestuarina (Bourne) & - & - & + & - \\
\hline Hirudinea & Piscicola geometra (L.) & - & - & - & + \\
\hline Oligochaeta & & - & - & + & + \\
\hline Nemertina & Prostoma obscurum Schultze & • & + & + & + \\
\hline \multirow[t]{2}{*}{ Turbellaria } & Dendrocoelum lacteum (O.F. Müller) & - & - & - & + \\
\hline & Planaria torva O.F. Müller & - & - & - & + \\
\hline lnsecta & Chironomidae & + & - & + & + \\
\hline \multirow[t]{3}{*}{ Pisces } & Zoarces viviparus (L.) & - & - & - & + \\
\hline & Pomatoschistus minutus (Pallas) & + & - & - & + \\
\hline & Pungitius pungitius (L.) & - & - & - & + \\
\hline
\end{tabular}


algae. After $16 \mathrm{~d}$ (A3), the algae in the net-bags showed clear signs of deterioration with a gradual formation of mats of sulphur bacteria (Beggiatoa spp.). Towards the end of the experiment (A5, 29 d), all algal net-bags were completely covered with bacteria. When removing algae during the experiment, epibenthic predators such as gobiids and brown shrimps Crangon crangon were observed to rapidly accumulate around/on the exposed plots, possibly exploiting stressed infauna at the sediment surface. At the end of the experiment, adult $N$. diversicolor were observed (individuals and characteristic burrows) under the algal treatments A4 and A5. N. diversicolor is known to be tolerant to hydrogen sulfide (Vismann 1990 ) and to function as an infaunal predator (Rönn et al, 1988)

\section{Hydrographical conditions during the experiment}

At the end of August and beginning of September, water temperatures decrease rapidly in the archipelago waters, and during the experiment average temperature in the bottom water declined from $\sim 16$ to $11^{\circ} \mathrm{C}$. The chlorophyll $a$ of the bottom water declined from $12 \mu \mathrm{g}^{-1}$ at the start of the experiment to 1.6 $\mathrm{g} \mathrm{I}^{-1}$ towards the end of the experiment. At the end of the experiment, slightly higher temperatures were recorded under the algal plots $\left(13^{\circ} \mathrm{C}\right)$ compared to the free bottom water $\left(11.5^{\circ} \mathrm{C}\right.$, Fig. 2a). Oxygen content decreased to moderately hypoxic conditions under the algal plots after only $9 \mathrm{~d}$ of exposure (Fig. 2b).

\section{POC/PON and loss on ignition}

The POC values of the algae showed a significant $(\mathrm{p}<0.05)$ initial decline from $180 \pm 17 \mathrm{mg} \mathrm{g}^{-1} \mathrm{dwt}$ to levels around $125 \mathrm{mg} P O C \mathrm{~g}^{-1} \mathrm{dwt}$, thereafter remaining constant over time. The same significant decline was recorded for PON. Despite a steady decline over time, there was no significant change in the POC/PON ratio of the algae. In the control treatments (bare sand) and the treatments under algae, the only significant changes were recorded under algae in treatment A5 (the last treatment before termination of the experiment). This treatment had significantly higher $(p<0.05)$ POC values $\left(18 \pm 8 \mathrm{mg} \mathrm{g}^{-1} \mathrm{dwt}\right)$ and POC/PON ratios ( $\mathrm{C} / \mathrm{N}$ ratio $19 \pm 6$ ) than all other treatments of both control and under algae (Fig. 3). No changes in loss on ignition between control and algal treatments were recorded during the course of the experiment, with values ranging between 0.41 and $0.53 \%$.
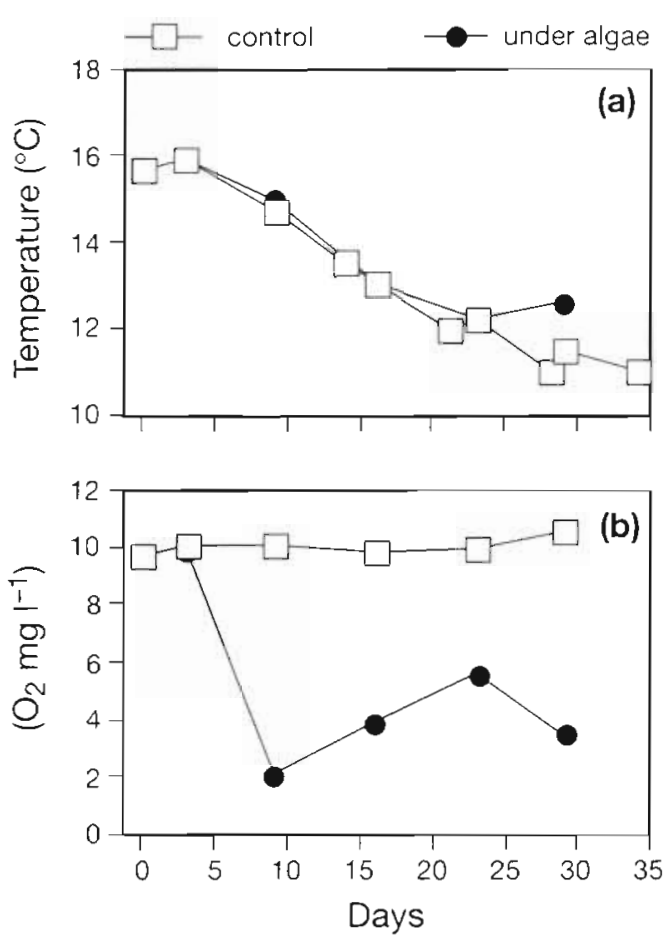

Fig. 2. Hydrographical conditions during the experiment in the free bottom-water (control) and under algae. (a) Temperature $\left({ }^{\circ} \mathrm{C}\right)$, and (b) oxygen concentration $\left(\mathrm{mg} \mathrm{I}^{-1}\right)$
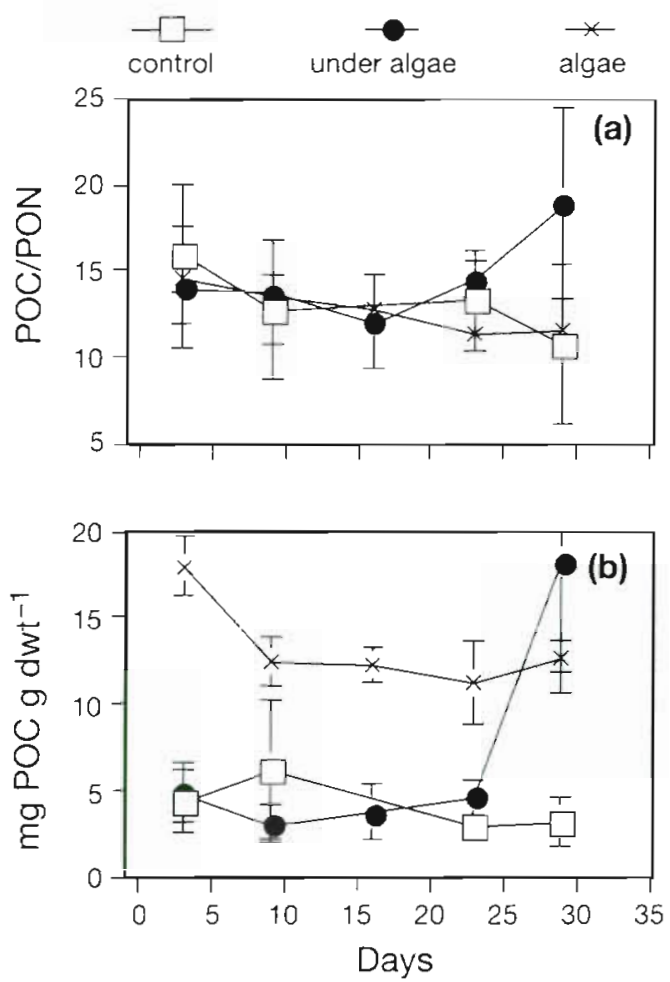

Fig. 3. Changes in (a) POC/PON ratios and (b) the fraction of $P O C$ in bare sand (control), under the algal plots and in the algae over the experimental time. Note that in (b) POC values for algae are divided by 10 


\section{Community structure under natural occurrences of algae}

The zoobenthic community sampled under naturally occurring algae had been exposed to drifting algal mats for approximately 1 mo. Community parameters exhibited significant reductions $(p<0.001)$ compared to controls (Fig. 4 , Tables $4 \& 5$ ). The average number of species found was $5.3 \pm 0.2$ on bare sand (Ref. sand, Fig. 1) compared to $2.0 \pm 0.6$ under algae (Ref. algae,
Fig 1), with oligochaetes as the dominant faunal component. Abundance values were reduced by $87 \%$ under the algae from $(24.2 \pm 5.2)$ to $(3.1 \pm 1.6) \times 10^{3}$ ind $\mathrm{m}^{-2}$. Biomass was reduced by $94 \%$ from $107 \pm 23$ to $7 \pm$ $3 \mathrm{~g} \mathrm{wwt} \mathrm{m}^{-2}$ (Fig. 4). Diversity $\left(H^{\prime}\right)$ was also found to be reduced from $1.54 \pm 0.17$ to $1.11 \pm 0.2$. Evenness $(J)$ showed higher values in Ref. algae $(0.79 \pm 0.08)$ compared to Ref. sand $(0.63 \pm 0.07)$, however, illustrating the dominance by oligochaetes.

Table 4. Statistıcal differences (Kruskall-Wallis; pair-wise comparisons) between no. of species (left side of table) and biomass (right side of table) for the different treatments. Levels of significance are given for all combinations of treatments tested. $\cdots p<0.001, \cdots p<0.01, \cdot p<0.05, n s:$ is not significant

\begin{tabular}{|c|c|c|c|c|c|c|c|c|c|c|c|c|c|c|c|c|c|c|c|}
\hline \multirow{2}{*}{\multicolumn{2}{|c|}{ Treatments }} & \multicolumn{18}{|c|}{ Levels of significance for biomass } \\
\hline & & ays & Ref.s & Ref. a & C1 & A1 & $\mathrm{C} 2$ & A.2 & $\operatorname{Rec} 1$ & $\mathrm{C} 3$ & A3 & $\operatorname{Rec} 2$ & $\mathrm{C} 4$ & A4 & $\operatorname{Rec} 3$ & $\mathrm{C} 5$ & A5 & $\operatorname{Rec} 4$ & C6 \\
\hline \multirow{17}{*}{ 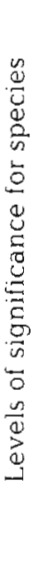 } & Ref. sand & 0 & & $\cdots$ & ns & ns & $\mathrm{ns}$ & $\cdots$ & $\cdots$ & ns & $\cdots$ & ns & ns & $\cdots$ & - & - & $\cdots$ & ns & ns \\
\hline & Ref. algae & 0 & $\cdots$ & & $\cdots$ & $\cdots$ & $\cdots$ & $\cdots$ & $\cdots$ & $\cdots$ & $\cdots$ & $\cdots$ & $\cdots$ & ns & $\cdots$ & $\cdots$ & $\cdots$ & $\cdots$ & $\cdots$ \\
\hline & Control 1 & 3 & ns & $\cdots$ & & $\cdots$ & ns & $\cdots$ & $\cdots$ & ns & $\cdots$ & ns & $\cdots$ & $\cdots$ & ns & ns & ns & ns & $\cdots$ \\
\hline & Algae 1 & 3 & $\cdots$ & $\cdots$ & $\cdots$ & & ns & ns & ns & • & $\cdots$ & $\cdot$ & ns & $\cdots$ & $\cdots$ & $\cdots$ & $\cdots$ & $\cdots$ & ns \\
\hline & Control 2 & 9 & ns & $\cdots$ & ns & ns & & $\cdots$ & $\cdots$ & ns & $\cdots$ & ns & ns & $\cdots$ & ns & ns & $\cdots$ & $\cdots$ & ns \\
\hline & Algae 2 & 9 & ns & $\cdots$ & ns & ns & ns & & ns & $\cdots$ & $\cdots$ & $\cdots$ & $\cdot$ & $\cdots$ & $\cdots$ & $\cdots$ & $\cdots$ & ns & ns \\
\hline & $\operatorname{Rec} 1$ & 14 & ns & $\cdots$ & ns & ns & ns & ns & & $\cdots$ & $\cdots$ & $\cdots$ & ns & $\cdots$ & $\cdots$ & $\cdots$ & $\cdots$ & ns & ns \\
\hline & Control 3 & 14 & ns & $\cdots$ & $n s$ & $\cdots$ & ns & ns & ns & & $\cdots$ & ns & ns & $\cdots$ & ns & ns & • & $\cdots$ & ns \\
\hline & Algae 3 & 16 & $\cdots$ & $\cdots$ & $\cdots$ & ns & $\cdots$ & $\cdots$ & $\cdots$ & $\cdots$ & & ns & $\cdots$ & ns & ns & ns & ns & $\cdots$ & $\cdots$ \\
\hline & $\operatorname{Rec} 2$ & 21 & $\cdots$ & $\cdots$ & $\cdots$ & ns & $\cdots$ & $\cdots$ & $\cdots$ & $\cdots$ & ns & & ns & $\cdots$ & ns & ns & ns & $\cdots$ & ns \\
\hline & Control 4 & 21 & ns & $\cdots$ & ns & $\cdots$ & ns & ns & $\cdot$ & ns & $\cdots$ & $\cdots$ & & $\cdots$ & $\cdots$ & $\cdots$ & $\cdots$ & ns & $n s$ \\
\hline & Algae 4 & 23 & $\cdots$ & ns & $\cdots$ & $\cdots$ & $\cdots$ & $\cdots$ & $\cdots$ & $\cdots$ & $\cdots$ & $\cdots$ & $\cdots$ & & ns & $\cdots$ & $\cdots$ & $\cdots$ & $\cdots$ \\
\hline & $\operatorname{Rec} 3$ & 28 & $\cdots$ & $\cdots$ & $\cdots$ & ns & $\cdots$ & $\cdots$ & $\cdots$ & $\cdots$ & ns & ns & $\cdots$ & ns & & ns & ns & $\cdots$ & $\cdots$ \\
\hline & Control 5 & 28 & ns & $\cdots$ & ns & $\cdots$ & ns & ns & ns & ns & $\cdots$ & $\cdots$ & ns & $\cdots$ & $\cdots$ & & ns & $\cdots$ & $\cdots$ \\
\hline & Algae 5 & 29 & $\cdots$ & ns & $\cdots$ & $\cdots$ & $\cdots$ & $\cdots$ & $\cdots$ & $\cdots$ & $\cdots$ & $\cdots$ & $\cdots$ & ns & $\cdots$ & $\cdots$ & & $\cdot$ & $\cdots$ \\
\hline & $\operatorname{Rec} 1$ & 34 & ns & $\cdots$ & $\cdot$ & ns & $\mathrm{ns}$ & ns & $\cdots$ & $\cdots$ & ns & ns & $\cdots$ & $\cdots$ & $\cdot$ & $\cdots$ & ns & & ns \\
\hline & Control 6 & 34 & $\cdots$ & $\cdots$ & $\cdots$ & $\cdots$ & $\cdots$ & $\cdots$ & $\cdots$ & $\cdot$ & $\cdots$ & $\cdots$ & ns & $\cdots$ & $\cdots$ & ns & $\cdots$ & $\cdots$ & - \\
\hline
\end{tabular}

Table 5. Statistical differences (Kruskall-Wallis; pair-wise comparisons and Wilcoxon signed-rank) between abundance in the different treatments (left side of diagram). Right side of diagram illustrates the normalized Euclidean distances between every pair of variables, based on the abundance of the 7 most dominant species. Levels of significance are given for all combinations of treatments tested. $\cdots p<0.001, \cdots p<0.01, " p<0.05$, ns: not significant

\begin{tabular}{|c|c|c|c|c|c|c|c|c|c|c|c|c|c|c|c|c|c|c|c|}
\hline \multirow{2}{*}{\multicolumn{2}{|c|}{ Treatments }} & \multicolumn{18}{|c|}{ Euclidean distances for abundance } \\
\hline & & ays & Ref. s & Ref a & $\mathrm{C} 1$ & A1 & $\mathrm{C} 2$ & A2 & Rec 1 & C3 & A3 & $\operatorname{Rec} 2$ & $\mathrm{C} 4$ & A4 & $\operatorname{Rec} 3$ & $\mathrm{C} 5$ & A.5 & $\operatorname{Rec} 4$ & C6 \\
\hline \multirow{17}{*}{ 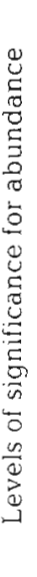 } & Ref. sand & 0 & & 60 & 23 & 40 & 39 & 19 & 481 & 14 & 56 & 145 & 34 & 59 & 72 & 30 & 61 & 72 & 32 \\
\hline & Ref algae & 0 & $\cdots$ & & 38 & 24 & 98 & 47 & 540 & 74 & 13 & 204 & 92 & 4 & 131 & 88 & 6 & 127 & 90 \\
\hline & Control 1 & 3 & ns & $\cdots$ & & 18 & 60 & 14 & 503 & 37 & 36 & 167 & 55 & 37 & 94 & 50 & 39 & 93 & 53 \\
\hline & Algae 1 & 3 & $\cdots$ & $\cdots$ & ns & & 77 & 25 & 519 & 54 & 28 & 183 & 71 & 23 & 109 & 66 & 24 & 111 & 69 \\
\hline & Control 2 & 9 & $\cdots$ & $\cdots$ & $\cdots$ & $\cdots$ & & 54 & 444 & 26 & 94 & 108 & 13 & 98 & 38 & 14 & 99 & 46 & 11 \\
\hline & Algae 2 & 9 & ns & $\cdots$ & ns & ns & $\cdots$ & & 494 & 32 & 48 & 158 & 47 & 46 & 85 & 42 & 47 & 91 & 45 \\
\hline & $\operatorname{Rec} 1$ & 14 & $\cdots$ & $\cdots$ & $\cdots$ & $\cdots$ & $\cdots$ & $\cdot$ & & 467 & 537 & 337 & 448 & .540 & 410 & 453 & 541 & 423 & 451 \\
\hline & Control 3 & 14 & ns & $\cdots$ & $\cdots$ & $\cdots$ & ns & $\cdots$ & $\cdots$ & & 70 & 131 & 21 & 73 & 59 & 19 & 75 & 59 & 20 \\
\hline & Algae 3 & 16 & $\cdots$ & $\cdot$ & ns & ns & $\cdots$ & ns & $\cdots$ & $\cdots$ & & 201 & 90 & 16 & 128 & 85 & 18 & 120 & 88 \\
\hline & $\operatorname{Rec} 2$ & 21 & $\cdots$ & $\cdots$ & $\cdots$ & $\cdots$ & ns & $\cdots$ & ns & $\cdots$ & $\cdot$ & & 112 & 203 & 51 & 117 & 204 & 95 & 115 \\
\hline & Control 4 & 21 & ns & $\cdots$ & $\cdots$ & $\cdots$ & $\mathrm{ns}$ & $\cdots$ & $\cdots$ & ns & $\cdots$ & ns & & 91 & 39 & 8 & 93 & 53 & 7 \\
\hline & Algae 4 & 23 & $\cdots$ & ns & $\cdots$ & $\cdots$ & $\cdots$ & $\cdots$ & $\cdots$ & $\cdots$ & ns & $\cdots$ & $\cdots$ & & 130 & 87 & 2 & 128 & 90 \\
\hline & $\operatorname{Rec} 3$ & 28 & $\cdots$ & $\cdots$ & $\cdots$ & $\cdots$ & ns & $\cdots$ & $\cdots$ & ns & $\cdots$ & ns & ns & • & & 45 & 131 & 51 & 42 \\
\hline & Control 5 & 28 & ns & $\cdots$ & $\cdot$ & $\cdots$ & $\cdot$ & $\cdot$ & $\cdots$ & ns & $\cdots$ & $\cdots$ & ns & $\cdots$ & - & & 88 & 58 & 5 \\
\hline & Algae 5 & 29 & $\cdots$ & ns & $\cdots$ & $\cdot$ & $\cdots$ & $\cdots$ & $\cdots$ & $\cdots$ & ns & $\cdots$ & $\cdots$ & ns & $\cdots$ & $\cdots$ & & 129 & 91 \\
\hline & $\operatorname{Rec} 1$ & 34 & $\cdots$ & $\cdots$ & $\cdots$ & $\cdots$ & ns & $\cdots$ & ns & $\cdots$ & $\cdots$ & ns & $\cdots$ & $\cdots$ & ns & $\cdots$ & - & & 55 \\
\hline & Control 6 & 34 & $\cdots$ & $\cdots$ & $\cdots$ & $\cdots$ & ns & $\cdots$ & $\cdots$ & ns & $\cdots$ & ns & ns & $\cdots$ & ns & ns & $\cdots$ & $\cdots$ & \\
\hline
\end{tabular}



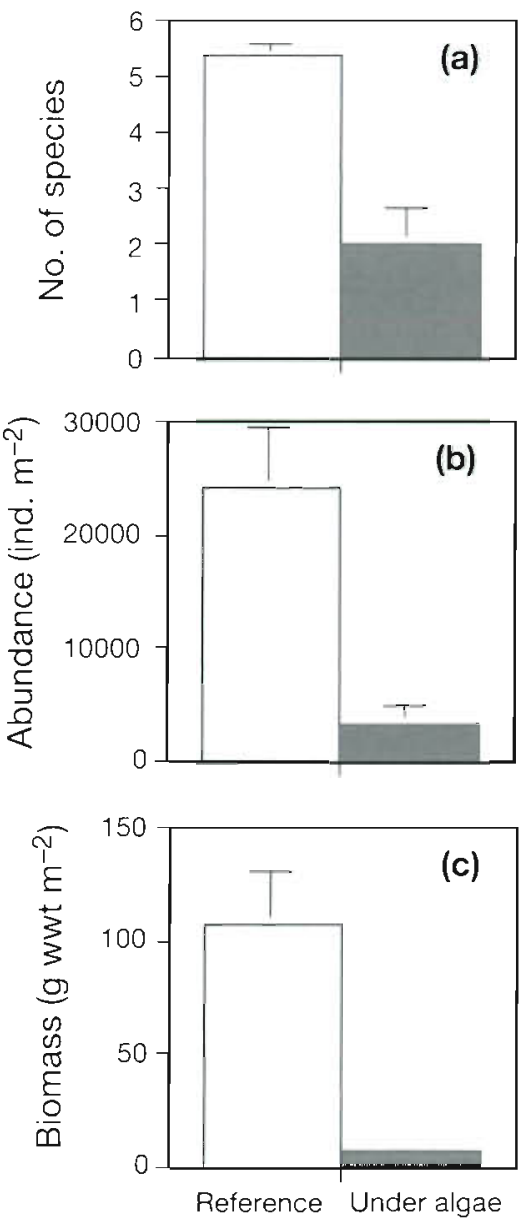

Fig. 4. (a) Species, (b) abundance and (c) biomass of the zoobenthic community exposed to natural accumulations of drifting algal mats over a period of 1 mo

\section{Changes in species, abundance and biomass under algal plots}

The zoobenthic community consisted of 17 invertebrate species/taxa (Table 3 ). The 7 most dominant species were Macoma balthica, Hydrobia sp., Pygospio elegans, Manayunkia destuarina, Nereis diversicolor, Prostoma obscurum and oligochaetes. A regression analysis revealed that mudsnails explained $91 \%$ of the total variation in abundance, whereas $M$. balthica explained $96 \%$ of the variation of total biomass in the data-set. The Kruskal-Wallis $H$-test gave significant differences in species numbers $(H=55.2$, df $=16, p<$ 0.0001). C6 (Fig. 1) differed significantly from all other control trcatments, illustrating the gradual increase in species number over time $(6.7 \pm 0.5$ species in $\mathrm{C} 6 \mathrm{com}$ pared to $5.5 \pm 0.5$ in $\mathrm{C} 1$; Fig. 5a) Despite a slight (nonsignificant) initial increase in species numbers under algae, from $4.5 \pm 0.3$ species in $\wedge 1$ to $5.2 \pm 0.6$ species in $\mathrm{A} 2$, the number of species showed a significant decline after 16 d (A3) compared to control treatments and A2. Toward the end of the experiment, only $1.8 \pm$ 0.5 and $2.2 \pm 0.5$ species were left in $\mathrm{A} 4$ and $\mathrm{A} 5$ respectively (Fig. 5a, Table 4).

Significant differences were also recorded in abundance $(H=78.0, \mathrm{df}=16, \mathrm{p}<0.0001)$ After an initial overshoot after $9 \mathrm{~d}(\mathrm{C} 2$, Fig. 1), the abundance values were relatively constant at levels of around $30 \times$ $10^{3}$ ind. $\mathrm{m}^{-2}$ in the control treatments (Fig 5b). There was a significant decline under algae (A2 vs C2) after $9 \mathrm{~d}$ of algal stress (Fig. 5b, Table 5). A rapid decline in abundance followed with a breakdown in A4 and A5, with an approximately $90 \%$ reduction compared to the control treatments $C 5$ and $C 6$. At the end of the experiment (A5), only $(3.2 \pm 1.2) \times 10^{3}$ ind. $\mathrm{m}^{-2}$ remained under algae compared to $(33.2 \pm 2.9) \times 10^{3}$ ind. $\mathrm{m}^{-2}$ in C6 (Fig. 5b, Table 5).
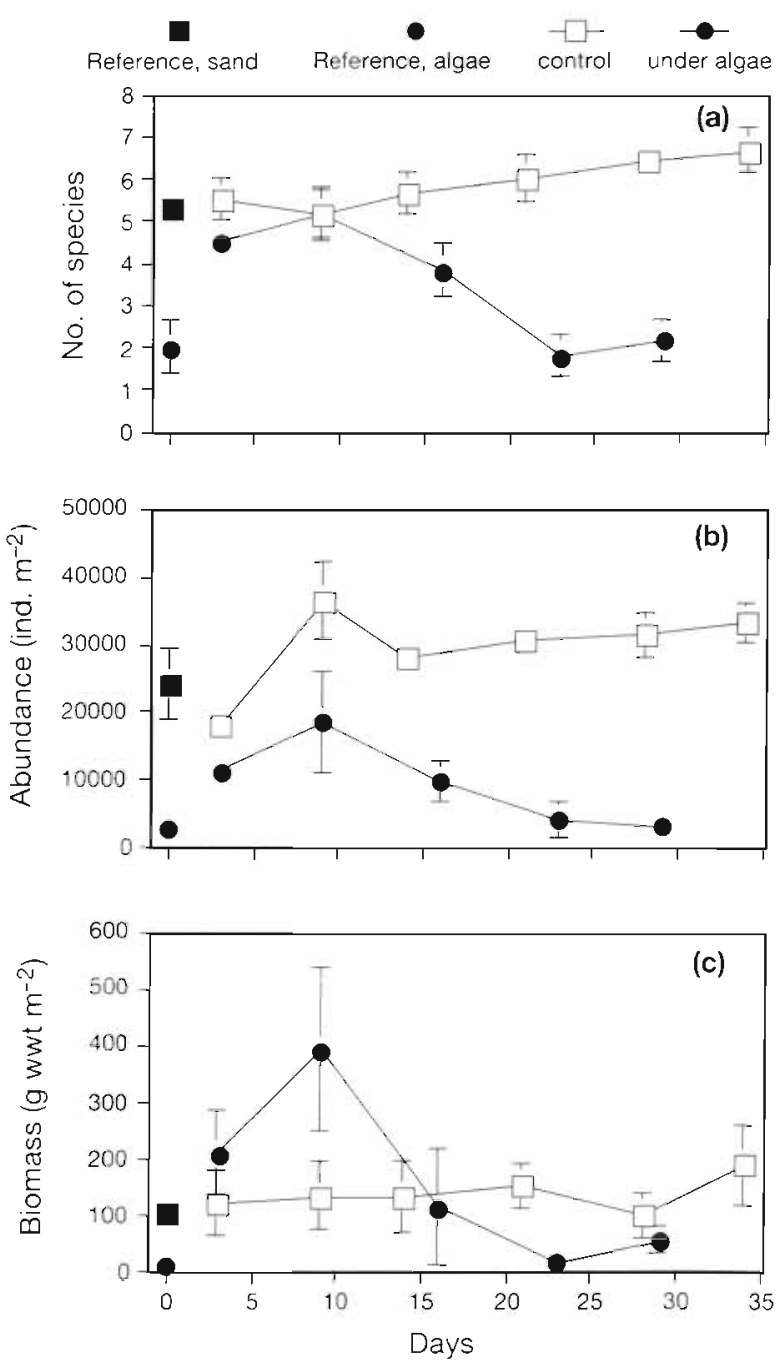

Fig. 5. Comparison of (a) species, (b) abundance and (c) biomass under algae ( $440 \mathrm{~g} \mathrm{dwt} \mathrm{m}^{-2}$ ) and control (no algal cover). Note the reference treatments (Ref. sand and Ref. algae) 
Biomass values were less consistent than the species and abundance patterns, probably due to the great inherent variability in the adult fraction of the Macoma balthica population ranging between 98 and $188 \mathrm{~g} \mathrm{wwt} \mathrm{m}^{-2}$ in control treatments and 19 and $393 \mathrm{~g}$ wwt $\mathrm{m}^{-2}$ in the algal treatments (Kruskal-Wallis; $H=$ 38.4, $\mathrm{df}=16, \mathrm{p}<0.0013)$. C4 and C6 had significantly higher biomass than $\mathrm{C} 1$ and $\mathrm{C} 5$ (Fig $5 \mathrm{c}$, Table 4). The biomass under algae showed a significant increase after 9 d (Fig. 5c, Table 4), increasing from $209 \pm 73 \mathrm{~g} \mathrm{wwt} \mathrm{m}^{-2}$ in A1 to $393 \pm 145 \mathrm{~g} \mathrm{wwt} \mathrm{m}^{2}$ in A2. A2 differed significantly from all other treatments except A1 and C6 (Table 4). This is probably partly explained by adult $M$. balthica emerging closer to the sediment surface under the influence of algal cover, and partly by the stochastic occurrence of gastropods such as Theodoxus fluviatilis in the samples. Toward the end of the experiment (A.4 and A.5), biomass was significantly reduced $\left(19 \pm 14\right.$ and $55 \pm 24 \mathrm{~g} \mathrm{wwt} \mathrm{m}^{-2}$, respectively) compared to control treatments $\mathrm{C} 5$ and c6.

\section{Changes in community diversity under algal plots}

The initial diversity in the control treatment ( $C$. Fig. 1) was $1.82 \pm 0.07$ and was significantly $(p<0.05)$ reduced in the other, subsequent control treatments
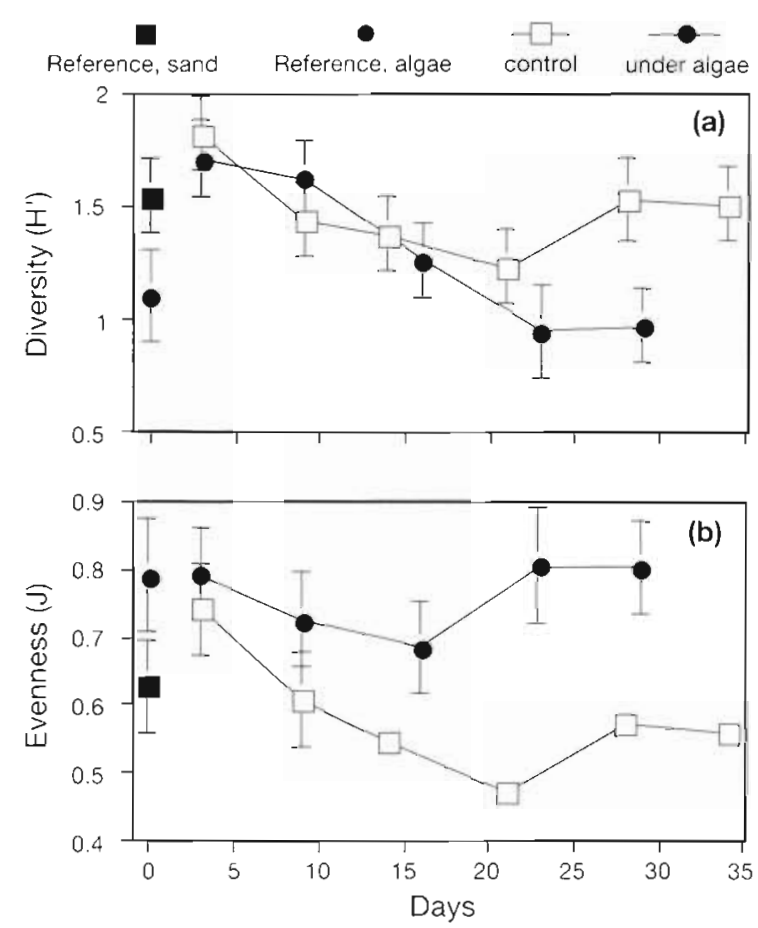

Fig. 6. Comparison of (a) diversity and (b) evenness under algae and control over the experimental time. Note the reference treatments (Ref. sand and Ref. algae)
(C2 to C6, Fig. 6a). Algal treatment A1 had a high diversity value (1.71) which then gradually declined $(\mathrm{A} 2=1.62$ to $\mathrm{A} 5=0.96)$. After $9 \mathrm{~d}(\mathrm{~A} 2)$, this decline was significant $(p<0.001)$ compared to A.1, stabilizing at low levels towards A4 and A5 (0.94 and 0.96, respectively). A4 and A.5 differed significantly $(p<0.05)$ from C4, C5 and C6, illustrating community breakdown under algae (Fig 6a).

Hicher values of evenness were found under algae compared to the control treatments, throughout the experiment. In the control treatments the initially high values declined from $0.74 \pm 0.07$ in $\mathrm{C} 1$ to $0.56 \pm$ 0.07 in $C 6$, illustrating the gradual recovery from stress imposed by the natural drifting mats which probably had occurred in the area at the start of the experiment (Fig. 6b). Despite an initial decrease in evenness under algae at the start of the experiment, the evenness values rose towards the end $(\mathrm{A} 4=0.81$ \pm 0.08 , and $\mathrm{A} 5=0.80 \pm 0.07$ ), illustrating the gradual takeover of community dominance by species indifferent to algal stress (mainly oligochaete species) (Fig. 6b). The differences between control and algal treatments were already significant $(\mathrm{p}<0.05)$ after 9 d (C2 vs A2, Fig 1).

\section{Short-term recovery after algal stress}

Recovery samples were taken $5 \mathrm{~d}$ after the algal netbags had been removed, from treatment $A 2$ onward. As the recovery samples were directly linked to the conditions after algal stress the Wilcoxon signed-rank test was performed and statistical power (df) was lost compared to the Kruskal-Wallis H-test (1 vs 16 df). For numbers of species, there was no significant difference in recovery from algal stress throughout the experiment (Fig. 7a, Table 4) and the 5 d recovery treatments failed to reach control levels. Although not significant, the recovery rates increased over time (Fig. $7 \mathrm{a}$, Table 4).

The impoverishment after algal stress was followed by overshoots in abundance in the recovery treatments (Fig. 7b) compared to both algal and control treatments. The recovery process was completely dominated by mudsnails (Hydrobia sp.). Recovery from the algal treatments A2 to A5 was significant $(p<0.05$; Fig. 7b. Table 5). Rec1 exceeded abundance values of A. 2 by $69 \%$ and C 3 by $53 \%(p<0.001)$. Rec 2 exceeded A 3 by $83 \%$ and C 4 by $47 \%(p<0.001)$ Rec 3 exceeded A 4 by $89 \%(p<0.05)$ and C5 by $14 \%$ (ns). Rec4 exceeded abundance values of $A 5$ by $93 \%$ and $C 6$ by $30 \%(p<0.01$; Fig. 7b, Table 5$)$.

Biomass recovery was less consistent compared to recovery patterns in species and abundance. A nonsignificant decrease was found between A2 and Rec1 

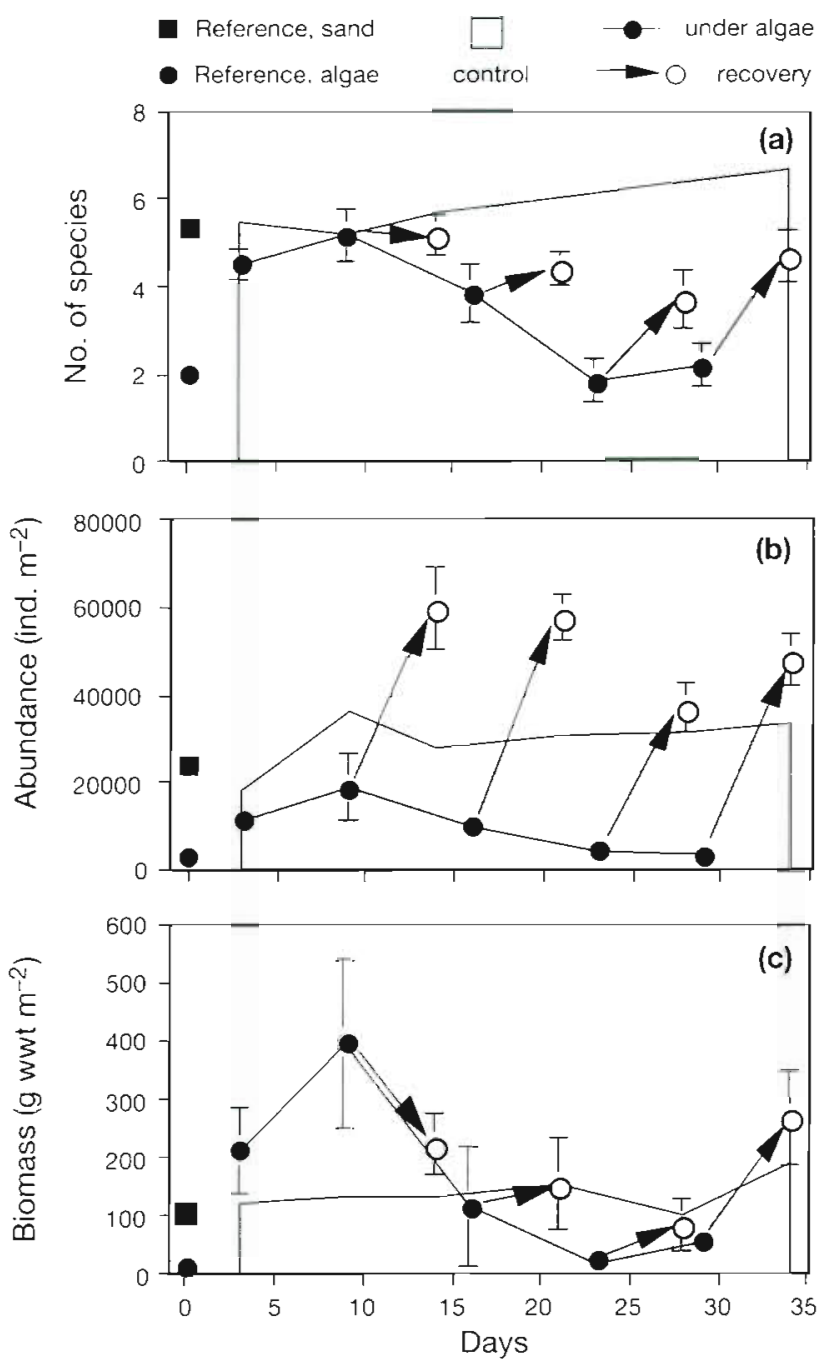

Fig. 7. Immediate recolonization rates for (a) species, (b) abundance and (c) biomass during a $5 \mathrm{~d}$ period after the removal of algal cover. Arrows indicate recolonization after stress. Shaded area indicates background control levels

$\left(393 \pm 145\right.$ to $221 \pm 54 \mathrm{~g}$ wwt $\mathrm{m}^{-2}$ ). Only Rec4 exhibited a significant $(\mathrm{p}<0.05)$ increase compared to A5 (from $55 \pm 24$ to $266 \pm 82 \mathrm{~g}$ wwt $\mathrm{m}^{-2}$ ). Only biomass values in Rec1 exceeded the control value of $\mathrm{C} 3$; all other recovery treatments were non-significant compared to their respective control treatments (Fig. 7C, Table 4).

The recovery treatments after algal stress (Rec1 to Rec5) exhibited lower diversity ( $H^{\prime}=0.82$ to 1.03 ) compared to the situation after the algal plots were removed $\left(H^{\prime}=1.62\right.$ to 0.96$)$, with only Rec2 differing significantly ( $p<0.05$ ) from A2 (Fig. 8a). Evenness values decreased significantly $(p<0.05)$ compared to algae (A2 to A5) and control (C2 to C5, Fig. 8b). The changes in diversity measurements ( $H^{\prime}$ and $J$ ) are largely governed by the presence or absence of Hydrobia sp.
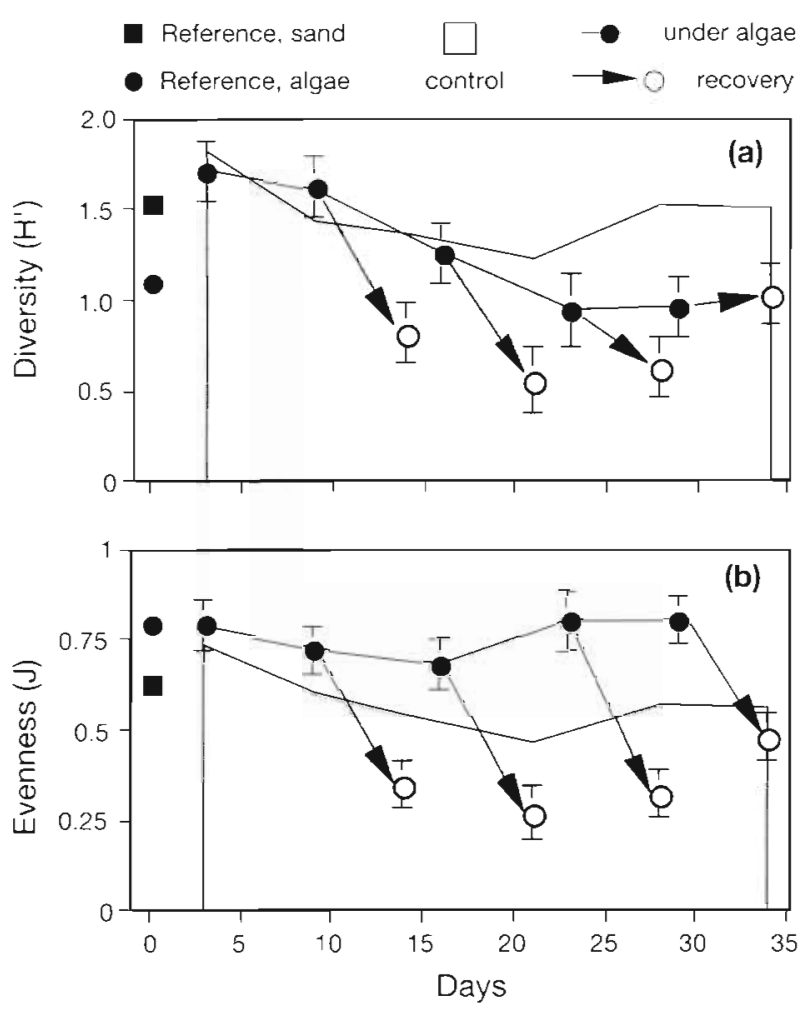

Fig. 8. Immediate recolonization as illustrated by changes in (a) diversity and (b) evenness during a $5 \mathrm{~d}$ penod after the removal of algal cover. Arrows indicate recolonization after

stress. Shaded area indicates background control levels

\section{Groupings of the data by means of hierarchical clustering}

The average-linkage clustering gave a dendrogram with clearly separate clusters (Fig. 9). All control treatments, initial algal treatments ( $A 1$ and $A 2$ ) and the reference from bare sand (Ref. sand) formed a cluster (Cluster 1, Fig. 9), where the Euclidean distances among the treatments within the cluster ranged between 4.8 and 76.9 (Table 5). Within Cluster 1 , the treatments $\mathrm{C} 2, \mathrm{C} 4, \mathrm{C} 5$ and $\mathrm{C} 6$ formed a group which possibly indicates the gradual increase of abundance in the control community. The degradation of the community under algae (algal treatments) from Day 16 onward (A3, A4 and A5), along with the situation under natural occurrences of algae (Ref. algae) produced a distinct Cluster 2 which was characterized by low internal distances, and large distances to the other clusters (Fig. 9, Table 5). The recovery treatments formed a heterogeneous group, illustrating the stochastic pattern of recovery and may only be regarded as a group in the sense that they are recovery phase samples (Fig. 9). Rec1 differed from all other treatments (distances ranging from 337 to 541 ; Table 5). 


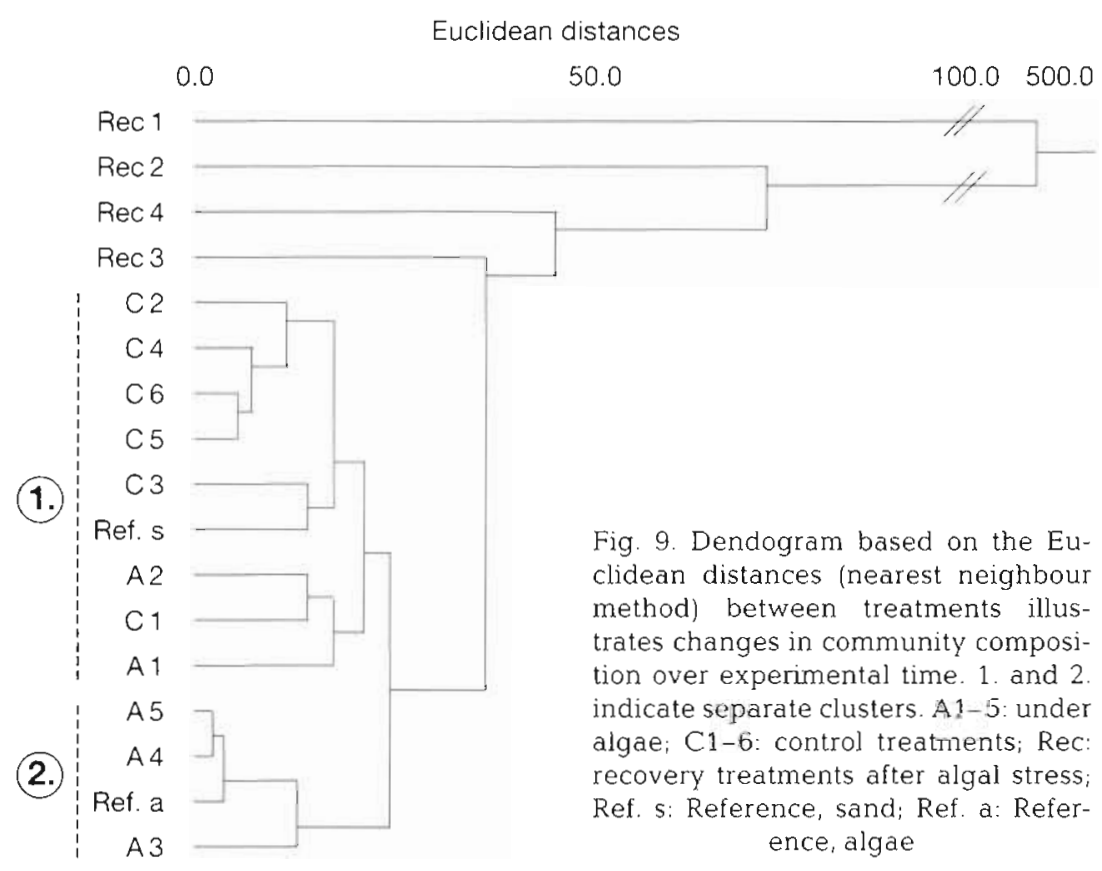

bance agent for the zoobenthos, drift algae have gained in importance and changed from a mere distorter and interrupter of community interactions with partly positive effects contributing to patch dynamics (i.e. intermediate disturbance through episodic occurrences), to a factor which has the potential to completely destroy the macrozoobenthic community.

\section{Decaying algae - organic loading and leakage of nutrients}

The algae are dominated by annual species (Table 1) pronouncing the annual cyclic phenomena of decaying algae. The dominants of the algal species (i.e. the Pilayella/ Ectocarpus-complex) exhibit clear seasonal variations in production

\section{Comparison between natural algal mats and experimental algal plots}

The situation under the last 2 algal treatments (A4 and A5) was similar to the situation under the natural occurrences of algal mats (Ref algae) in all measured community parameters, illustrating the power of the experiment in mimicking natural conditions. There was no significant difference between A5 and the situation under natural algae (Ref. algae) regarding species numbers, $A 5=2.2 \pm 0.5$ vs $2.0 \pm 0.6$ for Ref. algae (Fig. 5a, Table 4).

Abundance values in A5 were $(3.2 \pm 1.2) \times 10^{3}$ ind. $\mathrm{m}^{-2}$ compared to $(3.1 \pm 1.6) \times 10^{3}$ ind $\mathrm{m}^{-2}$ under natural algae (Ref, algae) (ns; Fig. 5b, Table 5). Similarily, there were no significant differences regarding biomass when comparing A4 (19 $\left.\pm 14 \mathrm{~g} \mathrm{wwt} \mathrm{m}^{-2}\right)$ and Ref. algae $\left(6.9 \pm 2.9 \mathrm{~g}\right.$ wwt $\left.\mathrm{m}^{-2}\right)$, although $\mathrm{A} .5 \mathrm{had}$ significantly higher biomass values (Fig. 5c, Table 4) The same trend was observed for community diversity with $H^{\prime}=0.96 \pm 0.17$ in $\mathrm{A} 5$ and $1.11 \pm 0.20$ in Ref. algae.

\section{DISCUSSION}

The results give conclusive evidence of the negative effects of drifting algal mats on coastal macrobenthic communities. As stated by Ólafsson (1988), drifting algal mats change in size, density and location in response to hydrodynamical conditions and the amount of drifting algae. With increasing eutrophication, increasing problems with drifting algal mats are expected. As a distur- and nutrient content with a pronounced peak in June, whereafter they are fragmented, detached and transported to the sediment communities as drift algae (Kautsky 1995). Considerable amounts of organic matter thus enter the benthic subsystems through the deposition of macroalgae from the littoral; Kautsky (1995) estimated the benthic primary production of the filamentous algae to constitute $-25 \%$ of the total coastal production (Swedish coast) on an annual basis. Similarly, Kautsky (1995) calculated that the detached filamentous algae contributed up to $50 \%$ of the annual input of POC to coastal sediment communities.

The benthic drift algal mat acts as an integrated biological entity, which depending on status of the algae might exhibit photosynthesis, decomposition, or both. The algal mats have been shown to induce hypoxia/ anoxia in the underlying sediment (Nicholls et al. 1981, Sundbäck et al. 1990, Norkko \& Bonsdorff 1996). This was also confirmed in the field and laboratory experiment. The measurements of oxygen under algae are somewhat uncertain and it is likely that oxygen levels were lower or even anoxic, since hydrogen sulfide odor was present in both cases. Decomposition of algal detritus is known to be mediated by bacteria and fungi (e.g. Tenore et al. 1984), and in both experiments, bacterial mats gradually developed, illustrating the ongoing decomposition of algae. The initial amount of POC in the algae was high, illustrating the considerable potential carbon source, and a significant decrease was registered. Only at the end of the experiment was a significant increase registered in the sediment under the algae, however, indicating mineralization taking 
place in the algal mat itself (Sundbäck et al. 1990). The higher POC values at the end of the experiment possibly illustrate higher nutritional levels in the sediment, which might stimulate bacterial production and subsequent immigration by epibenthic deposit feeders (Tenore et al. 1984, Levinton 1985). It is evident that the deposition of macroalgae to the sediment constitutes a large food source either directly or after bacterial enrichment, as illustrated by Vetter (1995), who recorded extremely high levels of benthic secondary production in connection to macroalgal debris in submarine canyons off the Californian coast (USA). This is also confirmed in the Baltic Sea, where the major pigment in guts of benthic fauna at the end of June to July originates from macroalgae (Kautsky 1995). Algal mats change nutrient fluxes from the sediment (Zimmerman \& Nontgomery 1984, Sundbäck et al. 1990). These fluxes have been shown to exhibit significant diel variation, whereas the respiration of the algae and sediment may cause oxygen deficiency (Thybo-Christesen et al. 1993). Higher temperatures were recorded under the algal mats which may further accelerate the decomposition process and the development of oxygen deficiency. Salinity stratification could cause such differences in temperature. Another explanation is that the algal mat affects hydrodynamic circulation (current flow) with a successive reduction of flow towards the base of the algae, and that higher temperatures are a consequence of internally produced heat (as a product of metabolism and/or decomposition of organic matter or in shallow littoral areas of solar heating), as pointed out by Escartin \& Aubrey (1995). Evidence from the aquarium experiment illustrates the potential of the decaying macroalgae to accelerate internal eutrophication by releasing nutrients (phosphorus) bound in the sediment and algae back into the water column (Sundby et al. 1992). Nutrient background levels in the laboratory experiment (control treatment) were high, possibly caused by bacterial production in the stagnant (no flow-through) water. As the algae constitute one of the most important factors inducing hypoxia/anoxia above the halocline in the northern Baltic Sea (Norkko \& Bonsdorff 1996). the normally oxic conditions in above-halocline sediments could be subject to inrreasing phosphorus release from the sediment due to algae-induced oxygen deficiency. This could further accelerate eutrophication.

\section{Habitat modifications induced by the algal mat and responses of the zoobenthic community}

The physical presence of the algal mat causes considerable habitat modifications for the zoobenthic community. The algal mat has been shown to form a phys- ical barrier structuring the zoobenthos at the initial phase of recruitment by the filtering of settling larvae (Ólafsson 1988, Bonsdorff 1992, Bonsdorff et al. 1995). Bonsdorff (1992) showed drifting algal mats to filter more than $70 \%$ of settling Macoma balthica larvae. Gaines \& Roughgarden (1985) emphasized the role of larvae as a determinant of zoobenthic community structure; the negative influences of the drift algal mats are further pronounced since adult infauna (i.e. M. balthica) are negatively influenced by drifting algal mats (sensu Bonsdorff et al. 1995). As shown by Nicholls et al. (1981), low oxygen concentrations in the underlying sediment would favour the algal mat as a habitat for macrofaunal species on the assumption that they have the capability (mobility) of taking advantage of the algae, and for epibenthic species such as mudsnails, this would be especially expected. In the field experiment, the algae were rapidly colonized by mudsnails. It is uncertain, however, to what degree mudsnails from the underlying sediment succeeded in vertical migrations up into the algae. In samples from the sediment under algae, we recorded considerable amounts of decomposing mudsnail shells

Infaunal species are known to respond to hypoxia by gradually leaving their protected position in the sediment and emerging at the sediment surface (Jørgensen 1980, Rosenberg et al. 1991). As illustrated by Norkko \& Bonsdorff (1996), the response to the combinations of hypoxia, hydrogen sulfide and the physical presence of the algal mat induces a more rapid response than mere hypoxia, illustrating the importance of physical cover and possibly toxic exudates from the algae (Johnson \& Welsh 1985, Anéer 1987). Everett (1994) argued that the presence of hydrogen sulfide and its toxicity (Theede et al. 1969) is the main factor inducing infaunal escape responses and mortality. Norkko \& Bonsdorff (1996) found $70 \%$ of the population of adult Macoma balthica to have emerged from the sediment after $17 \mathrm{~d}$ of algal cover. Perkins \& Abbott (1972) reported similar results with bivalves on the sediment surface, possibly avoiding the unfavourable conditions, and waders were reported to forage on unprotected bivalves. Norkko \& Bonsdorff (1996) illustrated the subtle effects of predation by epibenthic predators on prey stressed by temporary covers of drifting algal mats (i.e. effects of intermediate disturbance). In this study, the initial. increase in biomass under algae is probably a consequence of adult $M$. balthica emerging closer to the sediment surface. This would mean that adult clams were initially too deep in the sediment for effective sampling with the core-sampler used.

In a field survey conducted by Soulsby et al. (1982). opportunistic polychaetes such as Capitella capitata were found to be abundant under algal cover clearly 
being favoured by the presence of algae, and similar results have also been reported by others (e.g Thrush 1986, Raffaelli et al. 1991). In our study, oligochaete species fulfill the same functional role without declines in abundance under algal cover (Bonsdorff 1992, this paper). It seems evident that sedentary infauna such as bivalves and tubiculous species may experience high mortality, while mobile species may to some extent benefit from algal cover To a certain degree, local macrofaunal activity moved from the sediment to the algal mat, and it seems evident that the algal mats may function as an important rafting mechanism for invertebrate species (Gore et al. 1981), as well as a refuge from predation and an enriched trophic resource (Everett 1994) (Table 3). In a recent paper by Vetter (1994), sublittoral accumulations of algae were found to be inhabited by the highest densities of macrofauna ever found. Still. the drifting algae might be regarded as an insecure habitat for macrofaunal species because of the high degree of instability due to movement and degradation.

The zoobenthic community proved to be vulnerable to the exposure of drifting algae with a community breakdown after $16 \mathrm{~d}$ of algal cover. Structural differences were already found after $9 \mathrm{~d}$ of exposure. At the end of the experiment, the community breakdown was evident in all measured community parameters. When converting data to a larger scale, the effects of the drift algae become more apparent: 1 ha of bare sand (uncovered) sustains 242 million individuals and 1 t of benthic macrofauna, whereas 1 ha with algal cover sustains 31 million individuals and $0.007 \mathrm{t}(7 \mathrm{~kg})$. The natural occurrences of drifting algae in the sound were calculated to cover 2 ha, i.e. $1 / 3$ of the total area.

The field experiment proved to be a powerful tool in evaluating the effects of naturally occurring drifting algal mats, as well. All measured parameters were remarkably similar in both the experiment and the natural field situation. Community development under the algal plots showed decreasing Euclidean distances compared to the natural field situation, illustrating the increase in similarity over time (Table 5).

Despite the fact that algae occur during a restricted period during summer, the effects are severe and the reduction in the standing stock of zoobenthos is bound to have repercussions on higher trophic levels. The degradation of standing stock combined with the reduction of available feeding grounds could affect the flounder populations since adult Macoma balthica are known to be their major food source (Bonsdorff et al. 1995). Habitat degradation for epibenthic predators is also supported by our observations of dead fish entangled in the algae. The summer of 1994 was characterized by mass occurrences of benthic drift algae, and it was the first year we saw dead flounders on several occasions in connection with the algae (probably caused by $\mathrm{H}_{2} \mathrm{~S}$ poisoning).

\section{Short-term recovery after algal stress}

Depending on the severity of algal stress, different levels of resources such as space and food are liberated for colonizing species once the drift algal mat is disintegrated or transported away. Patches generated by the decay of algae may offer abundant food resources in the form of bacteria and decaying algal debris to opportunistic colonizers, such as oligochaetes and mudsnails Hydrobia sp. The total number of species available for recolonization is low in the northern Baltic Sea, however, and hence the early phases of recovery are primarily governed by season and the occurrence of different life stages of the dominant fauna (Bonsdorff \& Blomqvist 1993). Along with available resources, the initial community establishment in this study may be attributed to the short immigration distances (Günther 1992) and to the behavioural aspects of the immigrating species (Zajac \& Whitlatch 1982, Bonsdorff 1989). Despite rapid initial recovery, a considerable amount of time is required for the zoobenthic community to recover to pre-stressed conditions (Bonsdorff \& Österman 1985), and as pointed out by Bonsdorff \& Blomqvist (1993), community succession in the northern Baltic Sea largely follows the general pattern described for fully marine ecosystems by Pearson \& Rosenberg (1978). With increasing spatial and temporal scales of disturbance induced by drifting algal mats, the limited mobility of key species such as Macoma balthica will restrict the recolonization potential of the community. The absence of large benthic filter-feeders will therefore also alter local energy transfer in shallow coastal areas (Rosenberg \& Loo 1988, Peterson et al. 1994). With larger disturbed areas, it is likely that community succession will be determined by the available pool of larvae and pelagic settling. Since the peak settling and recruitment of many invertebrate species is synchronous with the occurrence of algae, however, community establishment might be unsuccessful.

\section{Concluding remarks}

Increasing amounts of drifting algae pose a significant threat to the coastal areas of the northern Baltic Sea. The phenomenon of drifting algae occurs in eutrophic coastal areas around the world. In contrast to algal mats in the intertidal, large amounts of detached algae may be present without being noticed in subtidal 
areas. Our study documents a severe deterioration of the zoobenthic community exposed to such algae in a Baltic coastal area. The deeper parts of the Baltic Sea have long been impoverished due to periodic or longterm hypoxia below the halocline, whereas the coastal areas above the halocline have been productive and important in maintaining biodiversity. These important shallow coastal areas are now seriously threatened by the occurrences of drifting algal mats.

Acknowledgements. We thank the Husö biological station for providing excellent working facilities. The Academy of Finland, Swedish Cultural Foundation and the Foundation of A bo Akademi University are acknowledged for financial support. We are grateful to staff and students at Husö for help with diving and field work. Dr Lisbeth Mathiesen from Aarhus University kindly helped in identifying the algae.

\section{LITERATURE CITED}

Anéer G (1987) High natural mortality of Baltic herring (Clupea harengus) eggs caused by algal exudates? Mar Biol 94: $163-169$

Bonsdorff E (1989) Infaunal colonization and its dependence on environmental variation - experimental evidence from the northern Baltic Sea. In: Ryland JS, Tyler PA (eds) Reproduction, genetics, and distribution of marine organisms. Proc 23rd Europ Mar Biol Symp. Olsen \& Olsen, Fredensborg, p 349-356

Bonsdorff E (1992) Drifting algae and zoobenthos - effects on settling and community structure. Neth $J$ Sea Res 30: $57-62$

Bonsdorff E, Aarnio $K$, Sandberg E (1991) Temporal and spatial variability of zoobenthic communttes in the archipelago waters of the Northern Baltic Sea - consequences of eutrophication? Int Revue ges Hydrobiol 76:433-449

Bonsdorff $E$, Blomqvist $E$ (1993) Biotic couplings on shallow water soft bottoms - examples from the northern Baltic Sea. Oceanogr mar Biol. A Rev 31:153-176

Bonsdorff E, Norkko A, Boström C (1995) Recruitment and population maintenance of the bivalve Macoma balthica (L.) - factors affecting settling success and early survival on shallow sandy bottoms. Proc 28th Eur Mar Biol Symp. Olsen \& Olsen, Fredensborg, p 253-260

Bonsdorff E, Österman CS (1985) The establishment, succession and dynamics of a zoobenthic community - an experimental study. In: Gibbs PE (ed) Proc 19th Eur Mar Biol Symp. Cambridge Unıversity Press, Cambrıdge. p 287-297

Cederwall H, Elmgren R (1980) Biomass increase of benthic macrofauna demonstrates eutrophication of the Baltic Sea. Ophelia Suppl 1:31-48

Cederwall H, Elmgren R (1990) Biological effects of eutrophication in the Baltic Sea, particularly the coastal zone. Ambio 19:109-112

Connell JH (1978) Diversity in tropical. rain forests and coral reefs. Science 199:1302-1310

Connell JH, Keough MJ (1985) Disturbance and patch dynamics of subtidal marine animals on hard substrata. In: Pickett STA, White PS (eds) The ecology of natural disturbance and patch dynamics. Academic Press, Orlando, p 125-151

Dybern BI, Ackefors $H_{i}$ Elmgren R (1976) Recommendations on methods for marine biological studies in the Baltic Sea Baltic Mar Biologists Publ 1:1-98

Escartin J, Aubrey DG (1995) Flow structure and dispersion within algal mats. Estuar coast Shelf Scl 40:451-472

Everett RA (1991) Intertidal distribution of infauna in a central California lagoon: the role of seasonal blooms of macroalgae. J exp mar Biol Ecol 150:223-247

Everett RA (1994) Macroalgae in marine soft-sediment communities: effects on benthic faunal assemblages. J exp mar Biol Ecol 175:253-274

Gaines G, Roughgarden J (1985) Larval settlement rate: a leading determinant of structure in an ecological community of the marine intertidal zone. Proc natl Acad Sci USA 82:3707-3711

Gore RH, Gallaher EE. Scotto LE, Wilson KA (1981) Studies on decapod crustacea from the Indian River region of Florida. XI. Community composition, structure, biomass and species- area relationships of seagrass and drift algaeassociated macrocrustaceans. Estuar coast Shelf Science 12:485-508

Grasshoff K, Ehrhardt M, Kremling K (1983) Methods of seawater analysis. Verlag Chemie, Weinheim

Gray JS (1992) Eutrophication in the sea. In: Colombo CC, Ferrari I, Ceccherelli VU, Rossi R (eds) Proc 23rd Eur Mar Biol Symp. Olsen \& Olsen, Fredensborg, p 3-1.3

Günther CP (1992) Dispersal of intertidal invertebrates: a strategy to react to disturbances of different scales? Neth J Sea Res 30:45-56

Haldin D (1994) Survey of hard bottom vegetation in the archipelago on NW Åland 1994. Forskningsrapporter frăn Husö biologiska station 90:1-56 (In Swedish with English summary)

HELCOM (1990) Second periodic assessment of the state of the marine environment of the Baltic Sea, 1984-1988; background document. Balt Sea Environ Proc 35b:1-432

Hull SC (1987) Macroalgal mats and species abundance: a field experiment. Estuar coast Shelf Sci 25:519-532

Isaksson I, Pihl L (1992) Structural changes in benthic macrovegetation and associated epibenthic faunal communities. Neth J Sea Res 30:131-141

Jumppanen K, Mattila J (1994) The development of the state of the Archipelago Sea and environmental factors affecting it. Lounais-Suomen vesiensuojeluyhdistys r.y. I, Turku (In Finnish with English summary)

Johnson DA, Welsh BL (1985) Detrimental effects of Ulva lactuca (L.) exudates and low oxygen on estuarine crab larvae. J exp mar Biol Ecol 86:73-83

Jorgensen BB (1980) Seasonal oxygen depletion in the bottom waters of a Danish fjord and its effect on the benthic community. Oikos 34:68-78

Kautsky H (1991) Influence of eutrophication on the distribution of phytobenthic plant and animal communities. Int Revue ges Hydrobiol 76:423-432

Kautsky U (1995) Ecosystem processes in coastal areas of the Baltic Sea. PhD thesis, Stockholm University

Lake PS (1990) Disturbing hard and soft bottom communities: a comparison of marine and freshwater environments. Aust J Ecol 1.5:477-488

Levinton JS (1985) Complex interactions of a deposit feeder with its resources: roles of density, a competitor, and detrital addition in the growth and survival of the mudsnail Hydrobia totteni. Mar Ecol Prog Ser 22:31-40

Mäkinen A, Aulio K (1986) Cladophora glomerata (Chlorophyta) as an indicator of coastal eutrophication. Publ Water Res Inst Finland 68:160-163

Nehring D, Matthäus W (1991) Current trends in hydrographic and chemical parameters and eutrophication in 
the Baltic Sea. Int Revue ges Hydrobiol 76:297-316

Norkko A (1993) Structuring and regulating forces on a soft bottom macrofauna community - a comparison of physical disturbance and predation. MSc thesis, Abo Akademi University (In Swedish with English summary)

Norkko A, Bonsdorff E (1996) Altered benthic prey-availability due to episodic oxygen deficiency caused by drifting algal mats. PSZN I: Mar Ecol 17(1): in press

Nicholls DJ, Tubbs CR, Hayes FN (1981) The effect of green algal mats on intertidal macrobenthic communities and their predators. Kieler Meeresforsch, Sonderh 5:511-520

Olafsson EB (1988) Inhibition of larval settlement to a soft bottom benthic community by drifting algal mats: an experimental test. Mar Biol 97:571-574

Pearson TH, Rosenberg R (1978) Macrobenthic succession in relation to organic enrichment and pollution of the marine environment. Oceanogr mar Biol A Rev 16:229-311

Perkins EJ, Abbott OJ (1972) Nutrient enrichment and sand flat fauna. Mar Pollut Bull 3:70-72

Peterson CH, Irlandi EA, Black R (1994) The crash in suspension-feeding bivalve populations (Katelysia spp.) in Princess Royal Harbour: an unexpected consequence of eutrophication. J exp mar Biol Ecol 176:39-52

Pickett STA, Kolasa J, Armesto JJ, Collins SL (1989) The ecological concept of disturbance and its expression at various levels. Oikos 54:129-136

Pickett STA, White DS (1985) The ecology of natural disturbance and patch dynamics. Academic Press, Orlando

Raffaelli D, Limia J, Pont S (1991) Interactions between the amphipod Corophium volutator and macroalgal mats on estuarine mudflats. J mar biol Ass UK 71:899-908

Reise K (1983) Sewage, green algal mats anchored by lugworms, and the effects on Turbelleria and small Polychaeta. Helgoländer Meeresunters 36:151-162

Rönn C, Bonsdorff E, Nelson WG (1988) Predation as a mechanism of interference within infauna in shallow brackish water soft bottoms; experiments with an infauna predator, Nereis diversicolor O. F. Müller. J exp mar Biol Ecol 116: $143-157$

Rosenberg R (1985) Eutrophication - the future marine coastal nuisance? Mar Pollut Bull 16:227-231

Rosenberg R, Hellman B, Johansson B (1991) Hypoxic tolerance of marine benthic fauna. Mar Ecol Prog Ser 79: $127-131$

Rosenberg R, Loo LO (1988) Marine eutrophication induced oxygen deficiency: effects on soft bottom fauna, western Sweden. Ophelia 29:213-225

Sachs L (1982) Applied statistics, a handbook of techniques. Springer-Verlag, New York

Sokal RR, Rohlf FJ(1981) Biometry. WH Freeman \& Co, San Francisco

Soulsby PG, Lowthion D, Houston M (1982) Effects of macroalgal mats on the ecology of intertidal mudflats Mar Pollut Bull 13:162-166

This article was presented by J. Gray (Senior Editorial Advisor), Oslo, Norway
Sousa WP (1984) The role of disturbance in natural communities. A Rev Ecol Syst 15:353-391

South GR, Tittley I (1986) A checklist and distributional index of the marine algae of the North Atlantic Ocean. Huntsman Marine Laboratory and British Museum (Natural History), St. Andrews and London

Strohl WR (1989) Family I Beggiotaceae Migula 1894. In: Staley JT, MP Bryant, Pfennig N, Holt JG (eds) Bergey's manual of systematic bacteriology, Vol 3. Williams \& Wilkins, Baltimore, p 2089-2105

Sundby B, Cobeil C, Silverberg N, Mucci A (1992) The phosphorous cycle in coastal marine sediments. Limnol Oceanogr 37:117-140

Sundbäck K, Jonsson B, Nilsson P, Lindström I (1990) Impact of accumulating drifting macroalgae on a shallow-water sediment system: an experimental study. Mar Ecol Prog Ser 58:261-274

Tenore KR, Hanson RB, McClain J, Maccubbin AE, Hodson RE (1984) Changes in composition and nutritional value to a benthic deposit feeder of decomposing detritus pools. Bull mar Sci 35:299-311

Theede H, Ponat A, Hiroki K, Schlieper C (1969) Studies on the resistance of marine bottom invertebrates to oxygen deficiency and hydrogen sulphide. Mar Biol 2:325-337

Thistle D (1981) Natural physical disturbances and the communities of marine soft bottoms. Mar Ecol Prog Ser 6 : 221-227

Thrush SF (1986) The sublittoral macrobenthic community structure of an Irish sea-lough: effects of decomposing accumulations of seaweed. J exp mar Biol Ecol 96:199-212

Thybo-Christesen M, Rasmussen MB, Blackburn TH (1993) Nutrient fluxes and growth of Cladophora sericea in a shallow Danish Bay. Mar Ecol Prog Ser 100:273-281

Vetter EW (1994) Hotspots of benthic production. Nature $372: 47$

Vetter EW (1995) Detritus-based patches of high secondary production in the nearshore benthos. Mar Ecol Prog Ser 120:251-262

Vismann B (1990) Sulfide detoxification and tolerance in Nereis (Hediste) diversicolor and Nereis (Neanthes) virens (Annelida: Polychaeta). Mar Ecol Prog Ser 59:229-238

Wallentinus I (1984) Comparisons of nutrient uptake rates for Baltic macroalgae with different thallus morphologies. Mar Biol 80:215-225

Williams Cowper S (1978) The drift algae community of seagrass beds in Redfish Bay, Texas. Contr Mar Sci 21. $125-132$

Zajac RN, Whitlatch RB (1982) Responses of estuarine infauna to disturbance. I. Spatial and temporal variation of initial recolonization. Mar Ecol Prog Ser 10:1-14

Zimmerman CF, Montgomery JR (1984) Effects of a decomposing drift algal mat on sediment pore water nutrient concentrations in a Florida seagrass bed. Mar Ecol Prog Ser 19:299-302

Manuscript first received: May 5, 1995

Revised version accepted: August 4, 1995 